\title{
Rotifer communities in Mediterranean ponds in eastern Iberian Peninsula: abiotic and biotic factors defining pond types
}

\author{
Maria Sahuquillo ${ }^{1,2, *}$ and Maria Rosa Miracle ${ }^{1}$ \\ ${ }^{1}$ Departament de Microbiologia i Ecologia, Institut Cavanilles de Biodiversitat i Biologia Evolutiva, Universitat \\ de Valencia, E-46100 Burjassot, València, Spain. \\ 2 Subdirecció General del Medi Natural, Generalitat Valenciana, València, Spain. \\ * Corresponding author: maria.sahuquillo@uv.es
}

Received: $15 / 02 / 18 \quad$ Accepted: $21 / 11 / 18$

\begin{abstract}
Rotifer communities in Mediterranean ponds in eastern Iberian Peninsula: abiotic and biotic factors defining pond types

We examined the rotifer community composition in 130 freshwater Mediterranean ponds which included a wide range of limnological characteristics. The objective was to test the effectiveness of rotifer assemblages in the identification of different ponds types and the forcing factors that determine their distribution. Among the environmental variables analysed hydroperiod stands out as a major factor separating true temporary ponds from those with permanent water stability. Abiotic and biotic factors showed a different relative importance in the two groups of ponds. Among the temporary ponds, abiotic variables, such as arid climate, turbidity and short hydroperiod defined a special group called argillotrophic, in which Rhinoglena frontalis was found to be the most characteristic rotifer species. Those temporary ponds with short hydroperiods supported few species (mean species richness 4) and, in the main, planktonic species. Permanent ponds supported higher species richness (mean 13 and maximum 33 species) composed mainly of littoral species. The rotifer community of permanent ponds was found to be correlated with biotic factors, such as fish and macrophyte abundance. High macrophyte cover favours complex habitat heterogeneity and a wider range of feeding traits, ranging from algae-grazing species to carnivorous species (Dicranophorus grandis or Cupelophagis vorax). These results showed that rotifer communities are useful to provide a typology of ponds with a hierarchical order of factors structuring them ranging from abiotic to biotic factors. This is an example of Stress Gradient Hypothesis being more significant in the heterogeneous Mediterranean area, and which may indicate trends of changes related to the conservation status or the effects of global warming.
\end{abstract}

Key words: stress gradient hypothesis, biodiversity, Rhinoglena, hydroperiod, temporary ponds, zooplankton

\section{RESUMEN}

Comunidades de rotiferos en charcas Mediterráneas en el este de la península Ibérica: factores abióticos y bióticos que definen los diferentes tipos de charcas

Se han estudiado las comunidades de rotiferos en 130 charcas mediterráneos con gran amplitud de características limnológicas. El objetivo es comprobar la efectividad de estas comunidades en la identificación de diferentes tipos de charcas, asi como lo factores que determinan esta distribución. Entre las variables ambientales analizadas, el hidroperiodo se destaca como factor principal, separando las charcas temporales de las permanentes con mayor estabilidad del medio. Posteriormente, factores abióticos y bióticos muestran una diferente importancia relativa dentro de cada uno de estos dos grupos de charcas. Entre las charcas temporales, factores abióticos, como clima árido, elevada turbidez e hidroperiodos cortos, definen un grupo especial de charcas temporales argilotróficas, en las que Rhinoglena frontalis es la especie de rotífero más característica. Estas charcas temporales con hidroperiodo corto tiene pocas especies de rotíferos (4 de media) y generalmente planctónicas. Las charcas permanentes tienen mayor riqueza de especies (13 de media 13 y un máximo de 33 especies) y más especies litorales. Estas comunidades de rotíferos de charcas permanentes están más relacionadas con factores bióticos, como la 
abundancia de peces y macrófitos. La elevada cobertura de macrófitos favorece una heterogeneidad del hábitat y una mayor gama de formas de alimentación, desde herbivoros hasta especies carnivoras (Dicranophorus grandis o Cupelophagis vorax). Estos resultados muestran que las comunidades de rotiferos son útiles para proporcionar una tipología de charcas y que existe un orden jerárquico de factores que las estructuran desde factores abióticos hasta factores bióticos. Un ejemplo de la hipótesis de gradientes de estrés, más significativa en la heterogénea área mediterránea, y que puede indicar la direccionalidad de cambios relacionados con el estado de conservación o los efectos del calentamiento global.

Palabras clave: hipótesis de los gradientes de stress, biodiversidad, Rhinoglena, hydroperiodo, charcas temporales, zooplancton

\section{INTRODUCTION}

Several studies have recently addressed the biodiversity of ponds, the factors driving different biological communities, and the utility of using community structure to define different pond typologies (Indermuehle et al., 2008; Céréghino et al., 2008; Miracle et al., 2010). While much work has been done on larger invertebrates and plants, rotifers, in spite of being an important component of the aquatic community has been neglected and less studied than other biological groups.

Rotifers are essential elements of freshwater ecosystems. They are important components of food webs due to their extremely high reproductive rates and their large populations (Walz, 1995). Sometimes they comprise the most important proportion of the zooplankton biomass (Wallace et al., 2006). Rotifers are often the most preferred prey for larger invertebrates such as copepods (Lapesa et al., 2002; Brandl, 2005) or small planktivorous fishes (Telesh, 1993). Their special biological characteristics make rotifers a model organism for ecological and evolutionary studies (Snell, 2014; Serra et al., in press). Moreover, they are a diverse group comprising about 2000 species (Segers, 2007) and are ubiquitous components of aquatic biocenosis. Rotifers have high dispersal abilities, are widely distributed in all types of inland waters and therefore generally thought to be cosmopolitan. However most rotifer species have their own biogeographical distribution pattern (Dumont, 1983) and include very specialised fauna which are sensitive to environmental changes (Angeler et al., 2010). Environmental variables identified to have significant effects on rotifer diversity include temperature, salinity or aquatic vegetation (Malekzadeh Viayeh \& Spoljar, 2012; Duggan et al., 2001; Guisande et al., 2008; Kaya et al., 2010). Sometimes these factors depend on the scale of the study. For example, within a single pond there are spatial differences between the open waters and the littoral area, or even species-specific preferences for microhabitats due to different types of macrophytes stands (Celewicz-Gołdyn \& Kuczyńska-Kippen, 2017). Differences in the trophic state, salinity or hydroperiod arise among groups of ponds (Mazuelos et al., 1993; Duggan et al., 2002; Wallace et al., 2005; Serrano \& Fahd, 2005). Expanding the analysis from a local to a regional level would provide additional insights of how climatic and biogeographical factors influence rotifer distribution (Duggan et al., 2002).

The Mediterranean basin shares common factors but it is considered a heterogeneous area. The diverse climate, geology and topography and the intense and long human footprint has resulted in a rich patchwork of habitats and landscapes (Blondel et al., 2010). One common feature is the irregular and scarce precipitation. In Mediterranean regions where water is scarce, small-sized aquatic habitats are abundant and extremely important due to their social and economic value as well as their ecological role in biodiversity. The maintenance of a good conservation status of these aquatic systems requires an adequate functioning of all their components. A good knowledge of every necessary step of their complex structure will provide further tools for their maintenance.

Our work was undertaken to study rotifer assemblages in Mediterranean ponds in the eastern Iberian Peninsula. We analysed 130 ponds arranged along a climatic and hydrological gradient. The accuracy of identifications and the high number of ponds studied helped improve our knowledge of the diversity of rotifers in the region. The main objectives of this study were: (1) to test the effectiveness of rotifer assemblages 


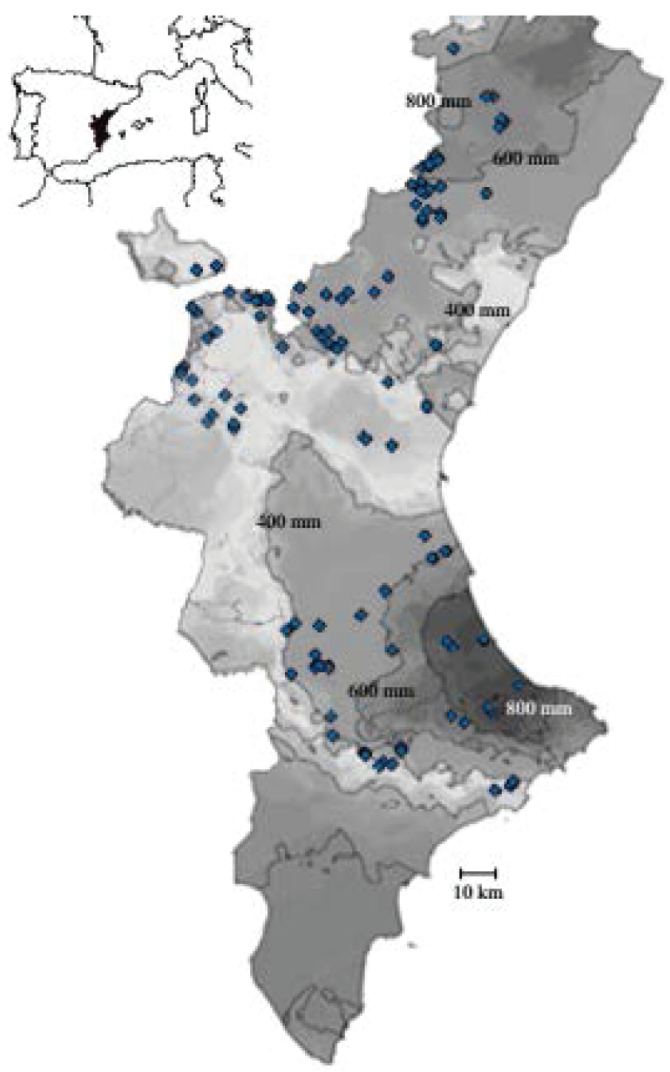

Figure 1. Geographical location of the 130 Mediterranean ponds studied in Comunitat Valenciana, eastern Spain. The isohyets show mean annual precipitation based on data for a 30 -year reference period. Darker shading indicates higher precipitation. Localización de las 130 charcas mediterráneas estudiadas en la Comunitat Valenciana. Las isoyetas muestran la precipitación media anual para un periodo de referencia de 30 años. Las zonas más oscuras corresponden a una mayor precipitación.

in the identification of different ponds types; (2) to identify environmental and water features that shape these communities; (3) to analyse differences in rotifer assemblages characteristic of the pond types, and; (4) to contribute to the knowledge of the biodiversity of rotifers, a neglected taxa in small ponds in the Mediterranean area.

\section{METHODS}

\section{The study area}

Locations of the ponds studied are shown in figure 1 . The study area has a typical Mediterra- nean climate with variations in rainfall from semi-arid (mean annual rainfall $300 \mathrm{~mm} /$ year) to sub-humid (above $800 \mathrm{~mm} / \mathrm{year}$ ), and in temperature from lowland warm areas to cooler mountains (mean annual temperature 17 and $9{ }^{\circ} \mathrm{C}$ respectively, Pérez Cueva, 1994). Small ponds are frequent in the study area (Sancho \& Lacomba, 2010) and include diverse environmental characteristics. The 130 ponds included in this study were all freshwater, shallow $(0.2-4.0 \mathrm{~m}$ depth) and small. The area of $50 \%$ of the studied ponds was $<200 \mathrm{~m}^{2}$ (only $4 \%>2000 \mathrm{~m}^{2}$ ). They cover a broad range of hydroperiod, from ephemeral rain-fed ponds to permanent ponds fed by groundwater. Thus, they constitute an appropriate dataset for investigating the influence of graded hydrological variation and pond limnology on rotifer composition. Physical and chemical characteristics of these ponds and some faunal communities were described in previous works (Sancho \& Lacomba, 2010; Sahuquillo \& Miracle, 2010; Sahuquillo et al., 2012; Sahuquillo \& Miracle, 2013 and Sahuquillo \& Miracle, 2015).

\section{Data collection}

We sampled ponds in 2006, 2007 and a few in 2008. Sampling was performed between February and early-May, to avoid early and late wet phases in the temporary ponds. Most ponds were sampled once but about $20 \%$ were sampled twice (in two different years to provide samples from two late winter-early spring periods). Rotifers were exhaustively sampled in littoral and open waters usually between 10:00 and 16:00. Semi-qualitative pelagic samples were taken using $40 \mu \mathrm{m}$ meshed plankton net in horizontal hauls. In littoral vegetated areas we used a $60 \mu \mathrm{m}$ handnet. Quantitative samples were obtained by filtering through a $30 \mu \mathrm{m}$ mesh between $4-16 \mathrm{~L}$ of depth-integrated water samples with a transparent tube $(1$ or $0.5 \mathrm{~m}$ long and $5 \mathrm{~cm}$ internal diameter) in different parts of the water column. Zooplankton samples were preserved in $4 \%$ formaline. For quantitative samples all specimens were identified and counted with an inverted microscope at 100x and results were expressed as individuals per litre. For net samples we counted sub-samples to obtain relative abundances, until 
Table 1. Categories of pond, based on hydroperiod, used in this study. Categorías de charcas, en función del hidroperiodo, utilizadas en este estudio.

\begin{tabular}{lll}
\hline Pond type based on hydroperiod & & Definition \\
\hline Temporary short hydroperiod ponds & TS & $<3$ months \\
Temporary intermediate hydroperiod ponds & TM & from 3 to 6 months \\
Temporary long hydroperiod ponds & TL & $>6$ months but with annual summer drying \\
Semi-permanent ponds & SP & dry every few years \\
Permanent ponds fed by groundwater & P & permanent \\
\hline
\end{tabular}

no statistical variation was observed or no other new species were found. Rotifer species were identified using Koste (1978). Rotifer carbon contents as mass were taken from Latja \& Salonen (1978), Telesh et al. (1998) and Lehtovaara \& Sarvala (unpublished) and converted to dry weight using a ratio of 2.5 .

Morphological (depth, area) and biological characteristics of ponds (plant coverage) were estimated in situ. In the central open water area we measured in situ water temperature, dissolved oxygen, conductivity and $\mathrm{pH}$ using WTW probes and we took a depth integrated sample of the water column with a transparent tube (as described above) for laboratory analysis of turbidity, alkalinity, planktonic chlorophyll- $a$, total phosphorus, total nitrogen and ammonium, following APHA (1992). We assigned a categorical variable to each pond indicating the main source of water $(1=$ rainfall, $2=$ surface waters and $3=$ ground waters) and one of five hydroperiod categories described in Table 1 based on our own observations. For each pond, several climatic parameters related to annual and spring rainfall, temperature and climate indices for a 30-year reference period (1960-1990) were obtained from the nearest meteorological station in Pérez Cueva (1994). More comprehensive information, including data on crustacean community composition and physical and chemical characteristics of water and sediments of the same ponds and pools were previously published in Sahuquillo \& Miracle (2012 and 2013). In fact, in this study we also tried to determine whether rotifer communities responded to environmental factors as crustaceans do in the same ponds, as we reported in Sahuquillo \& Miracle (2013).

\section{Data analysis}

1.- To find a pond typology we used multivariate analyses. Due to the large number of rotifer taxa identified, for these analyses we reduced the number of variables by grouping some taxa at the genus level. To obtain a representative composite sample for each pond, the relative percentages of rotifer taxa were averaged for each pond and date, these relative percentages were arcsine square root transformed to normalise the data. We conducted an initial ordination of rotifer taxa and ponds by detrended correspondence analysis (DCA) to check for differences in rotifer community composition and to estimate the species gradient length. DCA analysis was performed using the program Multivariate Statistical Package (MVSP 3.0 for Windows). Multivariate regression tree analysis (MRT), was used to look for (i) a hierarchical ordination of the variables affecting rotifer composition; (ii) a threshold value (cut-off value) of those variables that function as predictors and (iii) clusters of sites ('leaves'). The splits were chosen to minimise the Bray-Curtis dissimilarity index within clusters, and each split is defined by a simple rule based on environmental variables (De'Ath \& Fabricius, 2000; De'Ath, 2002). Predictive accuracy was estimated from the cross-validated relative error (CVRE), and CVRE minimum was used as the size of the best predictive tree ('pruned tree', De'Ath, 2002). MRT analyses were computed with the program R (Package mvpart version 1.2-6).

2.- In order to explore the differences in patterns of biodiversity among the different pond 
types, the following indices and estimators were calculated. Species richness was estimated as the total number of rotifer taxa recorded in each pond at each date (local species richness -or point species richness, Magurran, 2004). Differences in species richness, diversity and rotifer biomass among the different pond types are presented in box-plots with median and percentiles. Assumptions of normality and equal variance of data were checked prior to analysis and data were log or power transformed to improve normality of variables. ANOVA and post hoc Tukey tests for unequal sample sizes (Unequal N HSD) were applied to transformed variables to test for significant differences among pond types. Analyses were performed using PAST Statistics Software Package (Hammer et al., 2001)

The most characteristic species for each final pond type was selected from those having the highest indicator value INDVAL (Dufrêne \& Legendre, 1997) and with a significance of taxa association to typology $P<0.01$. This index is a measure to express species importance in community classifications. The analysis takes into account the relative abundance and frequency of occurrence of each taxon within the pond type and was performed using the software PC-ORD for Windows, 4.20, Oregon.

\section{RESULTS}

During this study a total of 109 monogonont rotifer taxa belonging to 35 genera were differentiated, of which 95 were identified to species (Table 2). The genus Lecane was, by far, the most diverse with 24 species, followed by Brachionus and Trichocerca with 7 identified species each. Bdelloids were also frequent in the ponds studied. In temporary ponds the rotifer community was dominated by planktonic species whilst plant-associated rotifers were the predominant population of permanent ponds.

\section{Rotifer ordinations}

A first ordination of ponds and rotifer taxa through DCA analyses showed the studied ponds ordered in a continuous gradient from more ephemeral ponds (TS) on the left side, to permanent ones (P) on the right one (Fig. 2). Among the rotifer species, the planktonic genera Rhinoglena, followed by Filina, Hexarthra and Brachionus reached the lowest values on this axis and were associated with temporary ponds with short to medium hydroperiod. On the opposite side, many species, mainly living on the littoral vegetated areas (Colurella sp., Cupelopagis vorax, Dicranophorus grandis, etc.), obtained high values on this axis and represent the more permanent ponds. Most samples were distributed along this first axis, while the second axis separated on the left those temporary ponds with a very short hydroperiod from those with a larger one (at the top of the graph). However hydroperiod had a lower effect on the right where more permanent ponds were grouped together. The results of the DCA ordination suggest an important role of hydroperiod on rotifer composition in the ponds.

\section{MRT analysis, forcing factors}

In a second stage, we applied MRT analysis to a matrix containing rotifer taxa and samples used for DCA analysis together with all limnological and climatic variables gathered. A first MRT analysis gave a two-leaf tree with the smallest estimated predictive error $(\mathrm{CV}=0.64)($ Fig. 3). This first split had the maximum drop in deviance (that is, the longest lengths of the vertical line segments), and further splits had lower importance. The first split was based on hydroperiod. This primary split separated the ponds into two groups: on the left are the permanent $(\mathrm{P})$ and semi-permanent ponds (SP) together with temporary ponds with long hydroperiod (TL), whilst on the right are temporary ponds with medium or short hydroperiod (TM and TS).

We also ran an un-pruned tree analysis to observe subsequent splits. Within the group of more permanent ponds, a second split separated at one side (leaf 1) permanent ponds $(\mathrm{P})$ with fish and mainly fed by groundwater. On the other side, semi-permanent ponds (SP) remained together with temporary ponds with long hydroperiod (TL). Among this last group of ponds, the plant coverage was a variable selected to subsequently 
Table 2. List of rotifer taxa and percentage of occurrence in temporary ( $\mathrm{TS}=$ temporary ponds with short hydroperiod, $\mathrm{TM}=$ medium hydroperiod, TL with long hydroperiod), semipermanent (SP) and permanent (P) study ponds. Lista de especies de rotiferos y porcentaje de ocurrencia en las charcas estudiadas. $T S=$ charcas temporales con hidroperiodo corto; $T M=$ hidroperiodo medio; $T L=$ temporales con hidroperiodo largo); $S=$ semi-permanentes; $P$ = permanentes.

\begin{tabular}{|c|c|c|c|c|c|}
\hline TAXA & TS & TM & $\mathrm{TL}$ & SP & $\mathrm{P}$ \\
\hline Bdelloidea & 42 & 39 & 33 & 78 & 80 \\
\hline Anuraeopsis fissa Gosse, 1851 & 9 & 2 & & 4 & 7 \\
\hline Ascomorpha ecaudis Perty, 1850 & & & & & 5 \\
\hline Asplanchna sp. & 2 & & & 4 & 9 \\
\hline Asplanchnopus hyalinus Harring, 1913 & & & & & 4 \\
\hline Asplanchnopus multiceps (Schrank, 1793) & & & & & 2 \\
\hline Brachionus angularis Gosse, 1851 & 4 & & & & 5 \\
\hline Brachionus variabilis Hempel, 1896 & & & & & 4 \\
\hline Brachionus quadridentatus Hermann, 1783 & 7 & & 67 & 2 & 4 \\
\hline Brachionus urceolaris Müller, 1773 & 15 & 18 & & & 4 \\
\hline Brachionus plicatilis Müller, 1786 & & & & & 2 \\
\hline Brachionus calyciflorus Pallas, 1766 & & & & & 4 \\
\hline Cephalodella gibba (Ehrenberg, 1830) & 2 & 2 & & 2 & 25 \\
\hline Cephalodella catellina (Müller, 1786) & & & & & 4 \\
\hline Cephalodella sp. & 24 & 48 & 83 & 37 & 40 \\
\hline Colurella adriatica (Ehrenberg, 1831) & 2 & & & 7 & 33 \\
\hline Colurella colurus (Ehrenberg, 1830) & & & & 4 & 15 \\
\hline Colurella hindenburgi Steinecke, 1916 & & & & & 2 \\
\hline Colurella obtusa Gosse, 1886 & 4 & 7 & & 9 & 18 \\
\hline Colurella uncinata (Müller, 1773) & & & & 7 & 11 \\
\hline Collotheca $\mathrm{sp}$. & & 5 & 17 & 2 & \\
\hline Cupelopagis vorax (Leidy, 1857) & & & & 4 & 18 \\
\hline Dicranophorus grandis (Ehrenberg, 1832) & & & & & 35 \\
\hline Euchlanis dapidula Parise, 1966 & & & & & 4 \\
\hline Euchlanis dilatata Ehrenberg, 1832 & 2 & 16 & 50 & 24 & 56 \\
\hline Encentrum martoides Fott, 1960 & & & & & 2 \\
\hline Encentrum plicatum Harring \& Myers, 1928 & & & & & 2 \\
\hline Encentrum longipes Wulfert, 1936 & & & & & 2 \\
\hline Epiphanes brachionus (Ehrenberg, 1837) & & 2 & & & \\
\hline Eosphora najas Ehrenberg, 1830 & & & & & 7 \\
\hline Filinia longiseta (Ehrenberg, 1834) & 25 & 25 & & 2 & 2 \\
\hline Floscularia sp. & & & & 2 & \\
\hline Hexarthra mira (Hudson, 1871) & 27 & 48 & & 13 & \\
\hline Hexarthra intermedia (Wiszniewski, 1929) & 4 & & 17 & & \\
\hline Hexarthra sp. & & 2 & 17 & 4 & 2 \\
\hline Keratella cochlearis (Gosse, 1851) & & & & 2 & \\
\hline Keratella tropica (Apstein, 1907) & 2 & 2 & 67 & 11 & 18 \\
\hline Keratella procurva (Thorpe, 1891) & 7 & & & 13 & \\
\hline Keratella quadrata (Müller, 1786) & 7 & 16 & 33 & 9 & \\
\hline Lecane bulla (Gosse, 1851) & 11 & 18 & & 15 & 49 \\
\hline Lecane aculeata (Jakubski, 1912) & & & & 2 & 15 \\
\hline Lecane bifurca (Bryce, 1892) & & & & & 4 \\
\hline Lecane closterocerca (Schmarda, 1859) & 11 & 23 & 17 & 26 & 36 \\
\hline Lecane cornuta (Müller, 1786) & & & & & 5 \\
\hline Lecane curvicornis (Murray, 1913) & & & & & 2 \\
\hline Lecane decipiens (Murray, 1913) & & & & & 2 \\
\hline Lecane doryssa Harring, 1914 & & & & & 2 \\
\hline Lecane flexilis (Gosse, 1886) & & & & 11 & \\
\hline Lecane furcata (Murray, 1913) & 2 & & & & \\
\hline Lecane grandis (Murray, 1913) & & & & & 4 \\
\hline Lecane hamata (Stokes, 1896) & 2 & & 33 & 7 & 35 \\
\hline Lecane hastata (Murray, 1913) & 2 & & & 2 & 4 \\
\hline
\end{tabular}




\section{Rotifers in Mediterranean ponds}

Table 2. (cont.)

Lecane hornemanni (Ehrenberg, 1834)

Lecane inermis (Bryce, 1892)

Lecane inopinata Harring \& Myers, 1926

Lecane levistyla (Olofsson, 1917)

Lecane ludwigii (Eckstein, 1883)

Lecane luna (Müller, 1776)

Lecane lunaris (Ehrenberg, 1832)

Lecane mira (Murray, 1913)

Lecane papuana (Murray, 1913)

Lecane punctata (Murray, 1913)

Lecane pyriformis (Daday, 1905)

Lecane quadridentata (Ehrenberg, 1830)

Lecane scutata (Harring \& Myers, 1926)

Lecane ungulata (Gosse, 1887)

Lecane sp.

Lepadella (Lepadella) patella (Müller, 1773)

Lepadella (Lepadella) triptera (Ehrenberg, 1832)

Lepadella (Lepadella) ovalis (Müller, 1786)

Lepadella (Lepadella) rhomboides (Gosse, 1886)

Lepadella (Lepadella) acuminata (Ehrenberg, 1834)

Lepadella $\mathrm{sp}$.

Lophocharis salpina (Ehrenberg, 1834)

Monommata aequalis (Ehrenberg, 1830)

Monommata actices Myers, 1930

Monommata sp.

Mytilina mucronata (Müller, 1773)

Mytilina ventralis (Ehrenberg, 1830)

Notholca acuminata (Ehrenberg, 1832)

Notholca squamula (Müller, 1786)

Notholca sp.

Notommata copeus Ehrenberg, 1834

Notommata haueri Wulfert, 1939

Polyarthra longiremis Carlin, 1943

Polyarthra vulgaris Carlin, 1943

Polyarthra sp.

Paradicranophorus sp.

Ptygura melicerta Ehrenberg, 1832

Ptygura sp.

Rhinoglena frontalis Ehrenberg, 1853

Scaridium longicaudatum Ehrenberg, 1830

Squatinella mutica Ehrenberg, 1832

Squatinella rostrum (Schmarda, 1846)

Synchaeta oblonga Ehrenberg, 1832

Synchaeta pectinata Ehrenberg, 1832

Synchaeta kitina Rousselet, 1902

Synchaeta sp.

Testudinella patina (Hermann, 1783)

Trichocerca pusilla (Jennings, 1903)

Trichocerca elongata (Gosse, 1886)

Trichocerca rousseleti (Voigt, 1902)

Trichocerca rattus (Müller, 1776)

Trichocerca elongata (Gosse, 1886)

Trichocerca longiseta (Schrank, 1802)

Trichocerca porcellus (Gosse, 1851)

Trichocerca sp. 


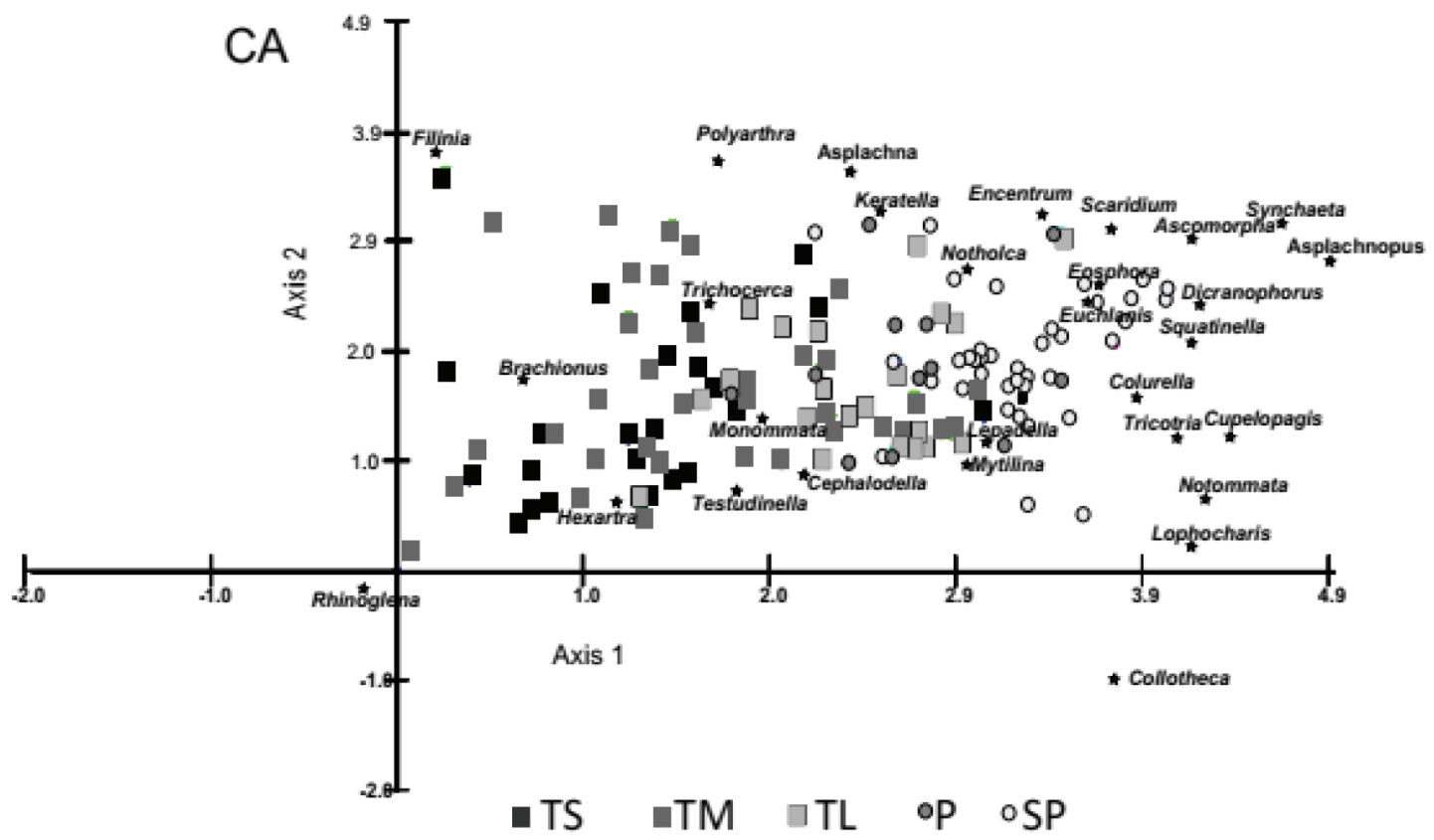

Figure 2. Biplot of samples (squares and circles) and species (stars) resulting from DCA ordination. Samples were classified according with hydroperiod classes used in this study: TS, black squares, Temporary short hydroperiod pools; TM, dark grey squares, Temporary intermediate hydroperiod pools; TL, light grey, Temporary long hydroperiod pools; SP dark grey circles, Semi-permanent ponds and P, light circles, permanent ponds. Biplot mostrando la ordenación de muestras (cuadrados y círculos) y especies (estrellas) resultantes del análisis DCA. Las muestras se clasificaron de acuerdo con las clases de charcas en función del hidroperiodo utilizadas en este estudio: TS, cuadrados negros, charcas temporales de hidroperiodo corto; TM, cuadrados grises oscuros, charcas de hidroperiodo intermedio temporal; TL, gris claro, charcas temporales de hidroperiodo largo; SP círculos gris oscuro, balsas semi-permanentes y $P$, circulos blancos, balsas permanentes.

differentiate rotifer communities in a group of ponds with macrophytes (leaf 2) from another group of SP and TL, with low plant coverage.

In the third split, the temporary ponds with short and medium hydroperiod (TS and TM) were separated into two groups. In this split, turbidity, spring precipitation and plant coverage were the selected variables, and defined a first group of ponds (leaf 4) located in wetter areas (with spring mean precipitation higher than 156 $\mathrm{mm}$ ) associated with clear waters and plant coverage higher than $15 \%$ of pond bottom. On the other side (leaf 5), those temporary ponds in more arid areas with clay turbid waters and low macrophyte coverage remain.

We then looked for a correspondence between the five leaves of ponds obtained from the MRT analyses and the ponds included previously in the categories based on hydroperiod (Table 1). We found a high correlation in the groups: leaf 1 corresponds to permanent ponds fed by groundwater (P); leaf 4 corresponds to temporary intermediate hydroperiod pools (TM) and leaf 5 corresponds to temporary short hydroperiod pools (TS). However, the leaves 2 and 3 do not fit well with established categories and temporary long hydroperiod pools (TL) and semi-permanent ponds (SP) were grouped together.

\section{Patterns of diversity among pond types}

Species richness varied considerably among the pond types, with an increasing trend along the gradient of water permanency (Table 2; Fig. 4) although the statistical test among different pond types, only became significantly higher in permanent ponds. Shallow temporary ponds with shorter hydroperiod had the fewest number of rotifer species, with a mean of 4 species per pond and date. However, a few temporary ponds had local 


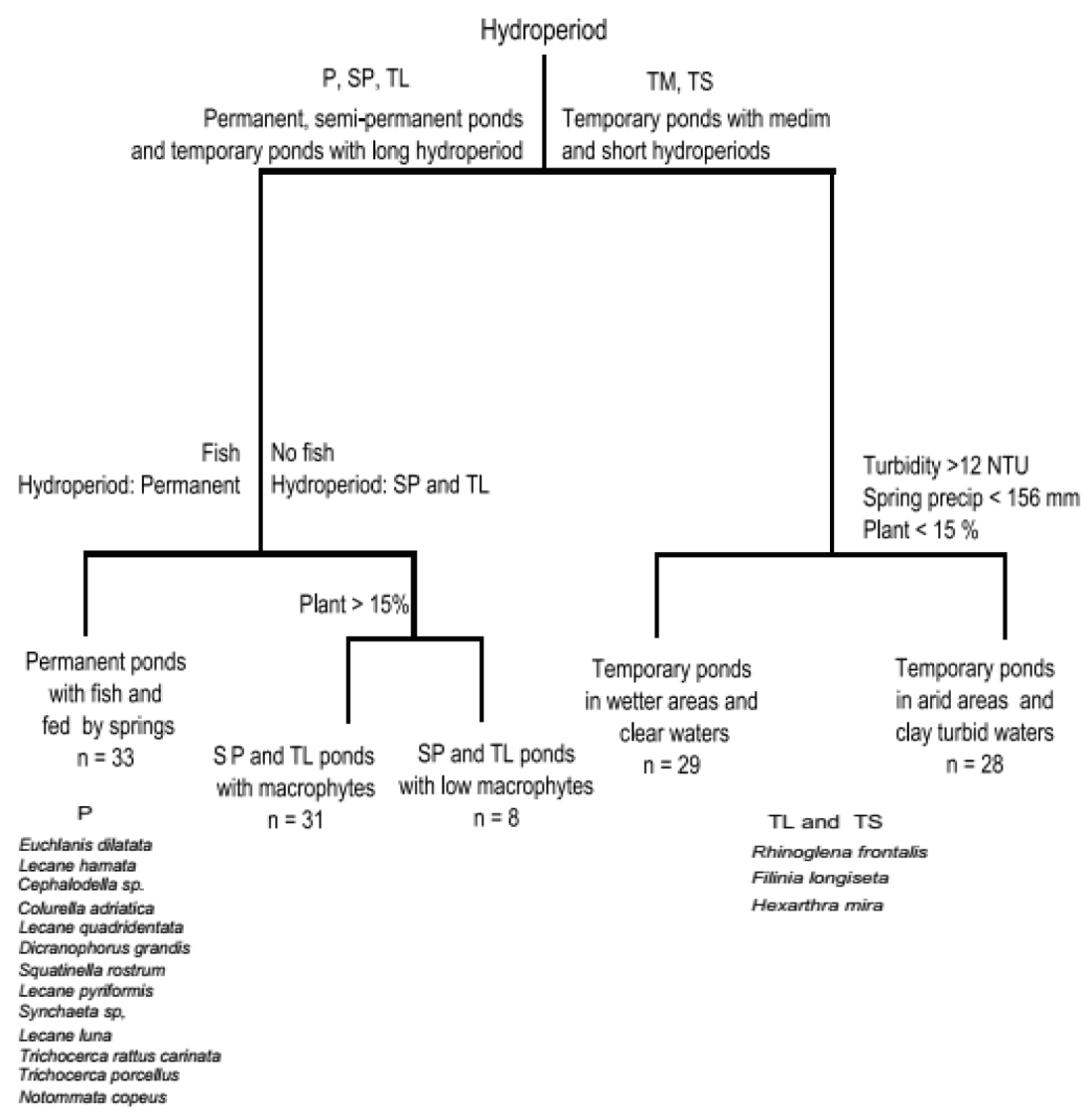

Figure 3. Multivariate regression tree (MRT) based on rotifer community composition from 130 ponds. The lengths of the vertical line segments are proportional to the drop in deviance corresponding to each split and the labels for each node show the variables selected for the split and the thresholds. $\mathrm{n}=$ the number of studied ponds for each pond type. Abundant taxa with INDVAL scores $>$ 60 are shown at the bottom. Árbol de regresión multivariante (MRT) basado en la composición de la comunidad de rotíferos de 130 charcas estudiadas. Las etiquetas para cada nodo muestran las variables seleccionadas para la división y sus umbrales. $n=$ el número de charcas en cada tipo. Los taxones con valor INDVAL > 60 se muestran en la parte inferior.

species richness above 10 taxa, a number comparable with those from permanent ponds. The number of taxa increased slightly as the observed hydroperiod lengthened. At the opposite extreme, the group of permanent ponds had higher species richness, averaging 13 rotifer species and with a maximum of 33 taxa. Not surprisingly, the ponds with the greatest species richness were two clear permanent ponds fed by groundwater with dense macrophyte cover (named Fosc and Rajolar). These differences are even less clear when we look at Shannon diversity indices. The group of ponds fed by groundwater $(\mathrm{P})$ presented maximum values of diversity. Nevertheless, among the other groups diversity values were similar to each other. Although we observed a certain tendency towards increased diversity with more stable aquatic habitats, differences were not statistically significant. Rotifer biomass in plankton samples was low in the more permanent ponds (groups $\mathrm{P}$ and TL), but quite variable within the rest of the groups. The low biomass was due to low density of rotifers. In temporary ponds, although very variable we can found very high rotifer biomasses in plankton samples.

\section{INDVAL}

In temporary ponds only three taxa reached INDVAL scores higher than 60, therefore indicat- 


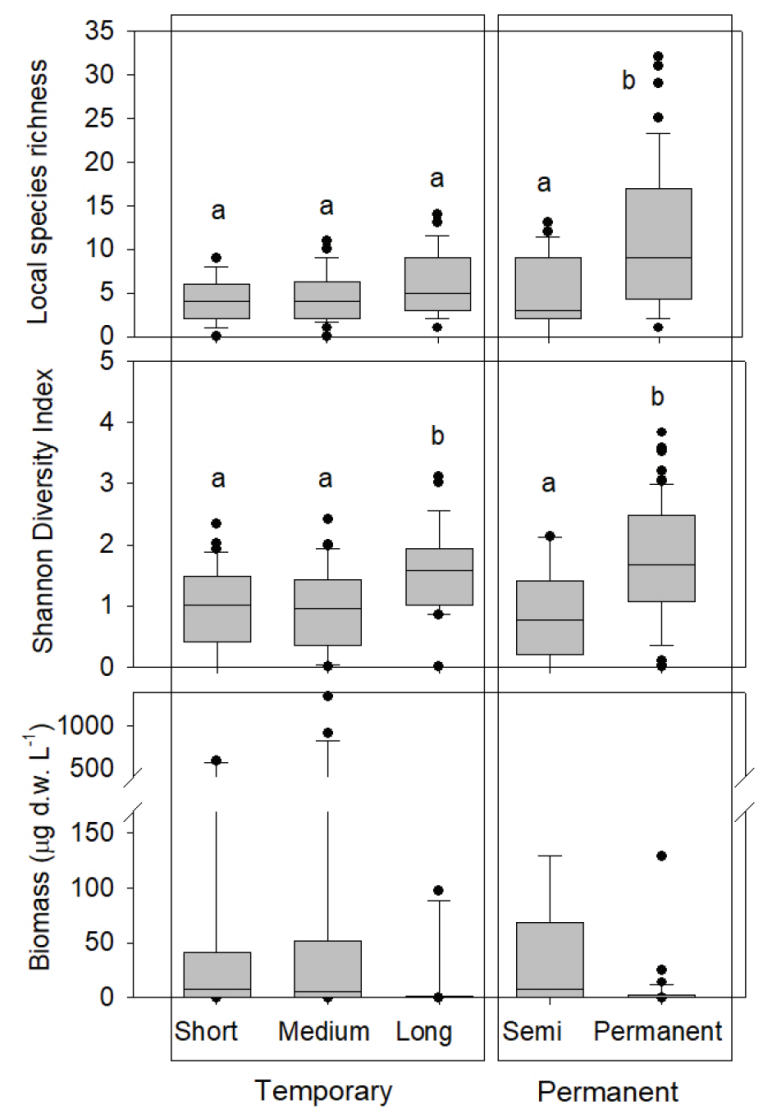

Figure 4. Boxplots showing several diversity estimators for each pond type: Local species richness was calculated for individual samples (i.e., per pond and sampling date), Shannon diversity index and rotifer biomass. Diagramas de caja mostrando los resultados de diversos estimadores de diversidad calculados para los diferentes tipos de charcas estudiados: riqueza local de especies (por charca y día de muestreo), indices de diversidad de Shannon y biomasa de rotiferos. Las letras sobre los gráficos indican los grupos significativamente diferentes (pruebas post-hoc de Tukey).

ing that these are typical species for this pond type. The low number of indicator species was expected as the total number of species per pond was also very low. These were all planktonic species. Rhinoglena frontalis reached highest INDVAL values in temporary ponds with short or medium hydroperiod. This species was quite frequent in our samples; we found it in 23 out of 35 temporary ponds (Table 2). Other species with high INDVAL values in temporary ponds with medium and short hydroperiod were Filinia longiseta and Hexarthra mira.
On the contrary, in the more permanent ponds with fish, a high number of species, 13 taxa, have significant INDVAL scores (Fig. 3), including some rare species such as Dicranophorus grandis, Squatinella rostrum, Lecane pyriformis or Notommata copeus. Most species found in these ponds have littoral preferences.

\section{DISCUSSION}

The extensive survey of ponds in a large variety of habitats allowed us to find a pond typology based on rotifer community. In addition these pond types also differ in the main structuring factors, in species richness, rotifer feeding traits and habitat preferences. Among the analysed environmental variables included in the studied freshwater ponds, hydroperiod was the environmental factor most strongly associated with the distribution of rotifer species. Although salinity has been identified as a crucial factor in determining rotifer abundance and diversity (Hammer, 1986), we analysed only freshwater ponds. Consequently, hydroperiod stands out as a major factor separating true temporary ponds from those with permanent water stability, as many studies have shown (Williams, 1998; Serrano \& Fahd, 2005; Marrone et al., 2006; Boix et al., 2007; Della Bella et al., 2008; Sahuquillo \& Miracle, 2013 and many others). Subsequently, abiotic and biotic factors showed different relative importance within the groups of temporary and permanent ponds.

Within temporary ponds, significant environmental variables which explain variability in rotifer communities include both abiotic (rainfall and clay turbidity) and biotic (macrophyte cover) factors. The abiotic variables highlight the role of water scarcity which define "harsh" habitats with very short hydroperiod and clay turbid waters. These argillotrophic temporary ponds are frequently found in Mediterranean arid areas and harbour very specialised taxa (Marrone et al., 2006). In our case, Rhinoglena frontalis was found to be the most characteristic rotifer species in this pond type. The apparent importance of inorganic turbidity explaining the distribution of Rhinoglena (MRT analyses showed that this is an important factor) may indicate that food plays a 
large role. Clay turbid water implies low primary producers and some fauna must be specialized in order to feed on bacteria and organic matter adsorbed in the suspended clay particles. Rhinoglena populations reached very high densities in plankton samples and so it may also play an important role as food for higher trophic aquatic inhabitants. Additionally, Rhinoglena was always found when temperatures were very low in winter and with clay turbid water. This is a widespread cold stenothermal species (Koste, 1978; Segers, 2007) which typically inhabits temporary habitats (Schröder, 2005). In our study area it was quite frequent in temporary ponds ( 23 ponds) with low water temperatures (preferably $5-10^{\circ} \mathrm{C}$ ) and low conductivity $(75-500 \mu \mathrm{S} / \mathrm{cm})$. Amazingly, this species was not found in other extensive studies of temporary ponds in the Iberian Peninsula (De Manuel, 1992 in Balearic islands and Guisande et $a l ., 2008$ or Serrano \& Fahd, 2005 in Doñana). In our study this species was found in cold mountain ponds and temperature could therefore be the limiting factor explaining this distribution. Those temporary ponds with short hydroperiods support few species $($ mean $=4)$. The number of taxa per pond was quite similar to those observed in Doñana ponds (Serrano \& Fahd, 2005) or in semi-arid ponds in Iran (Malekzadeh Viayeh \& Spoljar, 2012).

Within the permanent pond types, with more stable habitats, the rotifer community was found to be correlated with biotic factors, such as fish and macrophyte abundance. Most of the rotifer species found had littoral preferences. In these permanent ponds, with structurally complex habitats (high macrophyte cover) more refuges reduce predator foraging efficiency and also competition may increase diversity through increased habitat specialization (Menge \& Sutherland, 1976). Higher macrophyte cover supports higher habitat heterogeneity, food availability and refuge in a more stable environment and can also support more rotifer species. Not only the macrophyte density (Cyr \& Downing, 1988), but also the morphological structure influence zooplankton assemblages (Kuzinska-Kippen \& Nagengast, 2006). Moreover, competition favours a wider range of feeding traits, from algae-grazing species to carnivorous species. This is the case of the predatory rotifer Dicranophorus grandis and the littoral/sessile carnivorous Cupelophagis vorax. On the contrary, few cases of carnivorous rotifers have been documented in temporary ponds (Walsh et al., 2014). Permanent ponds as a whole held a higher number of species (120) than temporary ones, and local species richness was also higher (mean 13 and maximum 33 species). Not surprisingly, some permanent ponds with clear waters and high macrophyte cover sustain extremely high species richness in spite of their small area. Similar richness values were previously found in these habitats (Alfonso \& Miracle, 1987; Miracle et al., 1995) and these values are comparable to the ones obtained in larger water ecosystems considered to have high rotifer diversities. We consider these high richness values to result from a high sampling effort, great spatial habitat diversity, high habitat temporal stability and a good ecological status.

This hierarchical order of factors structuring these rotifer communities were also found for crustaceans in the same ponds (Sahuquillo \& Miracle, 2013). It is a good example of the importance of physical environment controlling organisms in harsh environmental conditions whilst biological interactions are more significant in more benign and predictable conditions (Lévêque, 1997). Many studies support this stress gradient hypothesis (SGH; Callaway, 2007) and perhaps it could be more significant in the heterogeneous Mediterranean area.

With respect to the main objectives of this study we found that rotifer communities can be used to classify ponds with contrasting limnological and climatic characteristics. First abiotic factors, and then biotic factors were identified to have a significant role on rotifer community distribution. Also, the results of this study contribute to the knowledge of rotifer fauna which has not been studied before in these ponds and showed the extraordinary richness of the rotifer assemblages in these environments. Traditionally, estimates of aquatic biodiversity have focused on permanent waters, however, temporary waters can make significant contributions to rotifer species richness and harbour high levels of endemism (Galindo $e t$ al., 1994; Walsh et al., 2014). We are far from fully understanding this fauna and we recognize 
that our study lacked more intensive seasonal sampling and /or interannual variability. In order to adequately manage and preserve these unique aquatic habitats, additional work will be needed to assess their biodiversity and to understand the processes regulating it.

\section{ACKNOWLEDGEMENTS}

This study was partly supported by the LIFE project Restoration of priority habitats for amphibians LIFE05 NAT/E/000060 of the Generalitat Valenciana. The authors are very grateful to all other participants in this project and especially to Eduardo Vicente and Sara Morata for their help with fieldwork and laboratory analyses and to Ignacio Lacomba and Vicente Sancho for assistance with fieldwork. Ricard Miracle is gratefully acknowledged for his assistance with MRT analyses and two anonymous referees improved the previous manuscript. With much gratitude to my mentor Rosa Miracle who started this work. It is a proud duty to complete it in her honour.

\section{REFERENCES}

ALFONSO, M. T. \& M. R. MIRACLE. 1987. Estudio comparativo del zooplancton en tres ullales del parque natural de la Albufera de Valencia. Limnetica, 3 (2): 263-272.

ANGELER, D. G., M. ALVAREZ-COBELAS \& S. SANCHEZ CARRILLO. 2010. Evaluating environmental conditions of a temporary pond complex using rotifer emergence from dry soils. Ecological Indicators, 10: 545-549.

APHA. American Public Health Association, 1992. Standard Methods for the Examination of the Water and Wastewater, 18th ed. Washington, DC

BOIX, D., S. GASCÓN, J. SALA, A. BADOSA, S. BRUCET, R. LÓPEZ-FLORES, M. MARTINOY, J. GIFRE \& X. D. QUINTANA. 2007. Patterns of composition and species richness of crustaceans and aquatic insects along environmental gradients in Mediterranean water bodies. Hydrobiologia, 597: 53-69. DOI: 10.1007/s10750-007-9221-z

BRANDL, Z. 2005. Freshwater copepods and rotifers: predators and their prey. Hydrobiologia, 546: 475-489. DOI: 10.1007/s10750-0054290-3

BLONDEL, J., J. ARONSON, J.-Y. BODIOU \& G. BOEUF. 2010. The Mediterranean region: Biological diversity in space and time. Oxford University Press, Oxford, UK.

CALLAWAY, R. M. 2007. Positive interactions and interdependence in plant communities. Dordrecht, Netherlands, Springer. DOI: 10.1007/978-1-4020-6224-7

CELEWICZ-GOŁDYN，S. \& N. KUCZYŃSKA-KIPPEN. 2017. Ecological value of macrophyte cover in creating habitat for microalgae (diatoms) and zooplankton (rotifers and crustaceans) in small field and forest water bodies. PLoS ONE 12(5): e0177317. DOI: $10.1371 /$ journal.pone.0177317

CÉRÉGHINO, R., J. BIGGS. B. OERTLI \& S. DECLERCK. 2008. The ecology of European ponds: defining the characteristics of a neglected freshwater habitat. Hydrobiology, 597: 1-6. DOI: 10.1007/s10750-007-9225-8

CYR, H. \& J. A. DOWNING. 1988. Empirical relationships of phytomacrofaunal abundance to plant biomass and macrophyte bed characteristics. Canadian Journal of Fisheries and Aquatic Sciences, 45(6): 976-984. DOI: 10.1139/f88-120

DE MANUEL, J., J. LL. PRETUS \& D. JAUME. 1992. Rotifers from the Balearic archipielago. Hydrobiologia, 239: 33-41. DOI: 10.1007/ BF00027527

DE'ATH, G. 2002. Multivariate regression trees: a new technique for modeling species-environment relationships. Ecology, 83: 1105-1117. DOI: 10.1890/0012-9658(2002) 083[1105:MRTANT]2.0.CO;2

DE'ATH, G. \& K. E. FABRICIUS. 2000. Classification and regression trees: a powerful yet simple technique for ecological data analysis. Ecology, 81: 3178-3192. DOI: 10.1890/00129658(2000)081[3178:CARTAP]2.0.CO;2

DELLA BELLA, V., M. BAZZANTI, M. G. DOWGIALLO \& M. IBERITE. 2008. Macrophyte diversity and physico-chemical characteristics of Tyrrhenian coast ponds in central Italy: implications for conservation. Hydrobiologia, 597: 85-95. DOI: 10.1007/s10750-007-9216-9 
DUFRÊNE, M. \& P. LEGRENDRE. 1997. Species assemblages and indicator species: the need for a flexible asymmetrical approach. Ecological Monographs, 67: 345-366. DOI: 10.1890/0012-9615(1997)067[0345:SAAIST] 2.0.CO;2

DUGGAN, I. C., J. D. GREEN \& R. J. SHIEL. 2001. Distribution of rotifers in North Island, New Zealand, and their potential use as bioindicators of lake trophic state. Hydrobiologia, 446/447: 155-164. DOI: 10.1007/978-94-0100756-6 22

DUGGAN, I. C., J. D. GREEN \& R. J. SHIEL. 2002. Distribution of rotifer assemblages in North Island, New Zealand, lakes: relationships to environmental and historical factors. Freshwater Biology, 47: 195-206. DOI: 10.1046/j.1365-2427.2002.00742.x

DUMONT, H. J. 1983. Biogeography of rotifers. Hydrobiologia, 104: 19-30. DOI: 10.1007/ 978-94-009-7287-2 4

GALINDO, M. D., L. SERRANO, H. SEGERS \& N. MAZUELOS. 1994. Lecane donyanaensis n. sp. (Rotifera: Monogononta, Lecanidae) from the Doñana National Park (Spain). Hydrobiologia, 284: 235-239. DOI: 10.1007/ BF00006693

GUISANDE, C., C. GRANADO-LORENCIO, J. TOJA \& D. LEÓN. 2008. Identification of the main factors in structuring rotifer community assemblages in ponds of Doñana National Park using the amino acid composition of the species. Limnetica, 27 (2): 273-284.

HAMMER, U. T. 1986. Saline lake ecosystems of the World. Dr W. Junk, Dordrecht.

HAMMER, Ø., D.A.T., HARPER \& P. D. RYAN. 2001. PAST: Paleontological Statistics Software Package for Education and Data Analysis. Palaeontologia Electronica 4 (1): 9 pp.

INDERMUEHLE, N., B. OERTLI, J. BIGGS, R. CÉRÉGHINO, P. GRILLAS, A. HULL, P. NICOLET \& O. SCHER. 2008. Pond Conservation in Europe: the European Pond Conservation Network (EPCN). Verhandlungen International Verein Limnologie, 30: 446-448. DOI: 10.1080/03680770.2008.11902163

KAYA, M., D. FONTANETO, H. SEGERS \& A. ALTINDAĞ. 2010. Temperature and salinity as interacting drivers of species richness of planktonic rotifers in Turkish continental waters. Journal of Limnology, 69 (2): 297-304. DOI: 10.3274/JL10-69-2-11

KOSTE, W. 1978. Rotatoria. Die Rädertiere Mitteleuropas. 2 volumes. Gebrüder orntraeger, Berlin, Stuttgart, Germany, Textband 673 pp., Tafelband 234 Tafeln.

KUCZYNSKA-KIPPEN, N. \& B. NAGENGAST. 2006. The influence of the spatial structure of hydromacrophytes and differentiating habitat on the structure of rotifer and cladoceran communities. Hydrobiologia, 559: 203-212. DOI: 10.1007/s10750-005-0867-0

LAPESA, S., T. W. SNELL, D. M. FIELDS \& M. SERRA. 2002. Predatory interactions between a cyclopoid copepod and three rotifer sibling species. Freshwater Biology, 47: 1693-1695. DOI: 10.1046/j.1365-2427.2002. 00926.x

LATJA, R. \& K. SALONEN. 1978. Carbon analysis for the determination of individual biomasses of planktonic animals. Internationale Vereinigung für Theoretische und Angewandte Limnologie: Verhandlungen, 20: 2556-2560. DOI: 10.1080/03680770.1977. 11896915

LÉVÊQUE, E. 1997. Biodiversity Dynamics and Conservation: The Freshwater Fish of Tropical Africa. Cambridge University Press.

MAGURRAN, A. E. 2004. Measuring biological diversity. Wiley. USA.

MALEKZADEH VIAYEH, R. \& M. SPOLJAR. 2012. Structure of rotifer assemblages in shallow waterbodies of semi-arid northwest Iran differing in salinity and vegetation cover. Hydrobiologia, 686: 73-89. DOI: 10.1007/ s10750-011-0992-x

MARRONE, F. \& G. MURA. 2006. Updated status of Anostraca, Notostraca and Spinicaudata (Crustacea Branchiopoda) in Sicily (Italy): review and new records. Il Naturalista siciliano, 30: 3-19

MARRONE, F., R. BARONE \& L. NASELLI FLORES. 2006. Ecological characterization and cladocerans, calanoid copepods and large branchiopods of temporary ponds in a Mediterranean island (Sicily, southern Italy). Chemistry and Ecology, 22: 181-190. DOI: $10.1080 / 02757540600557827$ 
MAZUELOS, N., J. TOJA \& C. GUISANDE. 1993. Rotifers in ephemeral ponds of Doñana National Park. Hydrobiologia, 255/256: 429-434. DOI: 10.1007/978-94-0111606-0_55

MENGE, B. A. \& J. P. SUTHERLAND. 1976. Species diversity gradients: synthesis of the roles of predation, competition and temporal heterogeneity. American Naturalist, 110: 350-369. DOI: $10.1086 / 283073$

MIRACLE, M. R., M. T. ALFONSO, E. VICENTE \& W. KOSTE. 1995. Rotifers of spring pools in the coastal marshland of Albufera of Valencia Natural Park. Limnetica, 11 (2): 39-47.

MIRACLE, M. R., B. OERTLI, R. CÉRÉGHINO \& A. HULL. 2010. Preface: conservation of european ponds-current knowledge and future needs. Limnetica, 29 (1): 1-8.

PÉREZ CUEVA, A. J. 1994. Atlas climático de la Comunidad Valenciana. Generalitat Valenciana. Conselleria de Obras Publicas, Urbanismo y Transportes, Valencia.

SAHUQUILLO, M. \& M. R. MIRACLE. 2010. Crustacean and rotifer seasonality in a Mediterranean temporary pond with high biodiversity (Lavajo de Abajo de Sinarcas, Eastern Spain). Limnetica, 29 (1): 75-92.

SAHUQUILLO, M., M. R. MIRACLE, S. M. MORATA \& E. VICENTE. 2012. Nutrient dynamics in water and sediment of Mediterranean ponds across a wide hydroperiod gradient. Limnologica, 42: 282-290. DOI: 10.1016/j.limno.2012.08.007

SAHUQUILLO, M. \& M. R. MIRACLE. 2013. The role of historic and climatic factors in the distribution of crustacean communities in Iberian Mediterranean ponds. Freshwater Biology, 58: 1251-1266. DOI: 10.1111/fwb. 12124

SAHUQUILLO, M. \& M. R. MIRACLE. 2015. Crustacean diversity and conservation value indexes in pond assessment: implications for rare and relict species. Limnetica, 2015: 333-348

SANCHO, V.\& I. LACOMBA. 2010. Conservación y Restauración de Puntos de Agua para la Biodiversidad. Generalitat Valenciana, Conselleria de Medi Ambient, Aigua, Urba- nisme i Habitatge, València.

SCHÖDER, T. 2005. Diapause in monogonont rotifers. Hydrobiologia, 546: 291-306. DOI: 10.1007/1-4020-4408-9 30

SEGERS, H. 2007. Annotated checklist of the rotifers (Phylum Rotifera), with notes on nomenclature, taxonomy and distribution. Zootaxa, 1564: 1-104.

SERRA, M, R. ORTELLS, E. GARCÍA-ROGER \& M. J. CARMONA. In press. Cyclically parthenogenetic rotifers and the theory of population and evolutionary ecology. Limnetica.

SERRANO L. \& K. FAHD. 2005. Zooplankton communities across a hydroperiod gradient of temporary ponds in the Doñana National Park (SW Spain). Wetlands, 25: 101-111. DOI: 10.1672/0277-5212(2005)025[0101: ZCAAHG]2.0.CO;2

SNELL, T. W. 2014. Rotifers as models for the biology of aging. International review of hydrobiology, 99 (1-2): 84-95. DOI: 10.1002/ iroh.201301707

TELESH, I. V. 1993. The effect of fish on planktonic rotifers. Hydrobiologia, 255/256: 289-296. DOI: 10.1007/BF00025851

TELESH, I. V., M. RAHKOLA \& M. VILJANEN. 1998. Carbon content of some freshwater rotifers. Hydrobiologia, 387/388: 355-360. DOI: 10.1007/978-94-011-4782-8 47

WALLACE, R. L., E. J. WALSH, M. L. ARROYO \& P. L. STARKWEATHER. 2005. Life on the edge: rotifers from springs and ephemeral waters in the Chihuahuan Desert, Big Bend National Park (Texas, USA). Hydrobiologia, 546: 147-157. DOI: 10.1007/s10750-005-4112-7

WALLACE, R. L., T. W. SNELL, C. RICCI \& T. NOGRADY. 2006. Rotifera: Volume 1. Biology, Ecology and Systematics. In Guides to the Identification of the Microinvertebrates of the Continental Waters of the World 23 Edited by: Dumont HJ. Leiden: Backhuys Publishers.

WALSH, E. J., H. A. SMITH \& R. L. WALLACE. 2014. Rotifers of temporary waters. Internationale Review of Hydrobiology, 99: 3-19. DOI: 10.1002/iroh.201301700

WALZ, N. 1995. Rotifer populations in plankton communities: Energetics and life history 
strategies. Experientia, 51: 437. DOI: 10.1007/ BF02143197

WILLIAMS, D. D. 1998. Temporary ponds and their invertebrate communities. Aquatic.
Conservation Marine and Freshwater Ecosystems, 7: 105-117. DOI: 10.1002/(SICI)10990755(199706)7:2<105::AID-AQC222>3.0. $\mathrm{CO} ; 2-\mathrm{K}$

Con el apoyo de:



